\title{
Life on the Edge: a perspective on precarious home ownership in
} Australia and the UK

\author{
Gavin A. Wood, Susan J. Smith, Melek Cigdem \& Rachel Ong \\ International Journal of Housing Policy (2015, online)
}

\begin{abstract}
This paper focusses on two countries with debt-funded ownership-centred housing systems, Australia and the UK. Financially, there are similarities between these two societies, which have relatively 'complete', reasonably well-regulated mortgage markets, had limited exposure to the extremes of subprime, and have been pre-occupied with (and reasonably successful in) restoring 'business as usual' in housing and mortgage markets. Institutionally, however, the countries differ from each other, notably with respect to the size and function of the rented sectors. By modelling matched datasets from panel surveys in Australia and the UK, this paper considers how home buying households in these financially similar, institutionally distinct, countries coped with the ups and downs of housing and mortgage markets in the first decade of the millennium. To address this, we focus on the edges of ownership: that once-stark boundary between owning and renting whose character is often taken for granted, yet which contains important signals about the functioning of housing systems, their link to the wider economy and the wellbeing of home occupiers. The analysis considers in hitherto unprecedented empirical detail how, why, when, for whom and in what way the edges of ownership proved precarious in the decade to 2010.
\end{abstract}

Keywords: Home ownership, edges of ownership, equity borrowing, panel surveys

\section{Introduction: the edges of ownership}

The debt debacle of the 2000s focussed attention onto the character and funding of mortgage owner occupation - the hitherto unquestioned centrepiece of most housing systems in the more developed world. It spawned a cascade of new research on financial products and services, on the interlinking of global financial flows with local economic affairs (Martin 2011; Smith 2013, 2915), and on the financial shocks that rocked the 'ordinary' economy, especially at the edges of owner occupation, particularly in the subprime sector, and notably in the USA (Langley 2008; Wachter et al. 2006). Picking up on some of these themes, we focus in this paper on two other countries with debt-funded ownership-centred housing systems, Australia and the UK. Financially, there are similarities between these societies, which (in contrast to the USA) have relatively 'complete', reasonably wellregulated mortgage markets, had limited exposure to the extremes of subprime, and have 1 
been pre-occupied with (and reasonably successful in) restoring 'business as usual' in housing and mortgage markets. Institutionally, on the other, hand the countries differ from each other (and from the USA), notably with respect to the size and function of the rented sectors.

How did home buying households in these financially similar, institutionally distinct, countries cope with the ups and downs of housing and mortgage markets in the first decade of the millennium? And what is the appropriate policy response? To address these questions, we focus on the edges of ownership: that once-stark boundary between owning and renting whose character tends to be taken for granted, yet which contains unacknowledged signals about the functioning of housing systems, their link to the wider economy and the wellbeing of home occupiers (Wood, Smith et al. 2013).

Conventionally, in the English-speaking world at least, the edges of home ownership are crossed just once in the life course, when young households step out of parental, or rental, accommodation and onto the so-called housing ladder. Access is secured through a small equity stake (or deposit) together with the leverage of a residential mortgage. Thereafter, owner occupation provides-among other things-a way of smoothing incomes across the life course, and a tax-advantaged investment vehicle that is traditionally retained until at, or near, the end of life. So when, at the turn of the millennium, it proved difficult for young households to accumulate deposits or support large enough mortgages to enter home ownership (not least because their incomes and savings are not protected against house price appreciation), it seemed logical to help them out. These credit rich years spawned a new range of 'affordability' products in both the UK (Scanlon and Whitehead 2004) and Australia (Whitehead and Yates 2010), which reduced deposit requirements and deferred capital repayments. This helped bridge the widening gap between renting and owning, but not, it turns out, to a sustainable extent.

Thanks to waves of over-expansion in a volatile or cyclic housing economy, for half a century at least there have been times when it was easier to slip out of ownership than to leverage in (Beer \& Faulkner 2009). Even recognising this, there is a temptation to regard the edges of ownership as a sharp divide, irrespective of the direction of travel. In our work, however, we prefer to conceptualise the edges of ownership as precarious, permeable, contested border zone in which there is a great deal of effort and activity. That is, the edges of ownership are complex, comprising: spaces which new entrants seek to vacate, as they establish their housing asset-base; positions to which those who struggle with housing costs may be forced to return; and locations wherein households actively juggle their savings, spending and debt 2 
as they attempt to retain a foot on the housing ladder. Using panel survey data for Australia and the UK for the decade to 2010 we consider in this paper, in fine-grained empirical detail, how, why, when, for whom and in what way the edges of ownership can be precarious. To that end, we focus specifically on the risk of exit from ownership. However, as we explain later, this forms part of a wider explanation as there is rather more 'churn' across the tenure divide than is generally appreciated.

\section{Setting the scene}

The empirical analysis draws on the nationally representative household panel data surveys for Australia and the UK: the survey of Household, Income and Labour Dynamics of Australia (HILDA); and the British Household Panel Survey (BHPS), together with its successor, Understanding Society (US). These data sources share some important common features that lend themselves to cross-country comparison. First, they offer a comprehensive range of variables pertinent to home ownership careers, including labour market, income, housing, health and other key socio-demographic indicators such as marital status and number of dependent children. Second, their longitudinal nature - and the fact that key questions are typically repeated in every wave - allows us to track individuals or households over time, linking biographical shifts, life transitions and external shocks with changes in individuals' housing and financial circumstances. Thirdly, similarities in survey structure and data collection methods mean that we can profile movements between home ownership and renting across a common timeframe for both countries.

The surveys collect detailed information for both households and individuals. We exploit the first ten waves of HILDA (2001-10), alongside the comparable waves of BHPS, to 2008 , to which we add a wave of BHPS-matched data from US. This latter is designed for continuity with BHPS, though BHPS panellists were not interviewed until the second wave, which is a data limitation (Laurie 2010). The numbers in the surveys are large: by constructing a balanced panel for 2001-2010 (that is, by retaining only those individuals for whom there is data for every studied year), we are able to follow the 5969 Australian and 5874 British residents who had at least one spell of owner occupation during that decade. The advantage of using such data is that they enable us to probe in unprecedented detail into the likelihood of exit from owner occupation across the massive financial shock of the mid-2000s.

The analysis follows spells of ownership, that is blocks of uninterrupted person-years (or episodes) of ownership. By working, first, with spells of ownership (one spell for every block of contiguous ownership years) we can recognise: a) that some individuals attain and retain 3 
ownership to the end of the study period (ongoing owners); b) that others exit and do not return during the period of observation (lasting leavers); and c) that a smaller number exit and return within the study period, sometimes more than once (these 'churners' are grouped with 'leavers' for the purposes of documenting exit, though we draw attention to some of their distinctive features from time to time). Ongoing owners and leavers have only one spell of ownership during the decade to 2010 , churners have at least two. In all, the analysis is based on 6830 ownership spells in Australia, and 6091 in the UK, and on 53,299 Australian, and 50,700 British person years in ownership.

The paper proceeds as follows. First, we describe and compare the likelihood of exit from ownership in Australia and the UK in the decade to 2010, with reference to life tables and hazard rates. Secondly, we estimate a discrete-time hazard regression model to identify the socio-economic characteristics, personal circumstances, and financial behaviours that affect the likelihood of exit. Thirdly, controlling for the effect of these individual predictors of exit, we speculate on institutional and other factors that might help account for cross-country differences in the loss of home ownership.

\section{The hazardous edge of the housing market}

Few would dispute the degree of financial stress to which home buying households were subject across the middle years of the decade to 2010 (Forrest and Yip 2011). Qualitative studies have been quick to document the adverse impact of the global financial crisis (GFC) on the financial and wider wellbeing of home occupiers (for a round up see Smith 2015); and the quantitative record increasingly bears this out (Burd-Sharps and Rasch 2015; Beer et al. 2013; Clark 2013). However, loss of home ownership is a very particular transition, and longitudinal studies of it are rare. Pickles and Davies $(1985,1986)$ made key early interventions in the literature tracking tenure shifts over time (see also Clark et al. 2003), but with respect to exiting owner occupation, while the Panel Survey of Income Dynamics has facilitated some detailed scrutiny in the USA (eg Berger et al. 2015; Turner and Smith 2009) in general such studies are rare. Furthermore, although we have used similar approaches ourselves when examining the drivers of movements in and out of housing affordability stress (Wood and Ong 2011; Wood et al. 2014) we believe the analysis that follows to be the first that has looked systematically at exit rates across this period, in either the UK or Australia

We therefore begin descriptively, using a life tables approach to track the ownership careers 
of the panel survey samples, from the start of the study period (2001) to its end (2010), following Singer \& Willett (2003, pp.326-330). Details are given in Table 1, which records the number of exits from ownership that occur as the length of each ownership spell increases. The following information is provided:

- $\quad$ Time, measured in intervals of one year, from the start of each spell, is in column 1.

- The interval between each measurement appears in column 2; it is always one year as the surveys return annually to the same households.

- Column 3 records the number of spells present at the start of each time period. For example, year zero is by definition (in this study) an ownership year (the first in the spell) so that all ownership spells for each country are present at that time. Effectively, this column represents the 'risk set' for a given point in an ownership spell: anyone present could potentially fall out of ownership before the next measurement.

- Column 4 records the numbers who do exit, and it can be seen from this that the majority exit early in a spell, and that, therefore, the bulk of person-years in the table refer to the first year of an ownership spell, and the minority to the ninth year.

- Column 5 shows the spells that are right-censored, and not included in the hazard and survival estimates ${ }^{1}$.

To describe the risks of exit, the 'common sense' measure is the hazard rate (given in table 1, column 6 and figure 1): it ranges from $0-1$, representing the proportion of households who entered a given year of a spell in owner occupation, and dropped out by the end of it. Easier to read, however, is the survival rate (column 7), which assesses the probability that a randomly selected owner-occupier will 'survive' in home ownership past a given year of a spell. In year zero, when no one has left ownership, its value is one. As spells lengthen and exits occur, the survivor function declines toward its lower limit of zero. These two measures are more or less the inverse of each other, though, unlike the hazard function, the survivor function will never increase.

[Table 1]

[Figure 1]

\footnotetext{
${ }^{1}$ Consider a person who transitions from rental to owner occupied housing in 2005 and then remains as an owner through to 2010 (the end of the study timeframe). This spell is described as right-censored; how the housing trajectory unfolds beyond 2010 is not recorded.
} 
Two points stand out. First, importantly, and counter-intuitively for the time period in question, the probability of losing owner occupation is low, in both countries. An estimated $90 \%$ of owner-occupiers in the UK, together with $76 \%$ of their Australian counterparts, could expect to continue in home ownership for more than eight years. Second, Australian hazard rates are notably higher than those in the UK, though the gap reduces slightly as spells lengthen. Third, the greatest risk of exit occurs in the early years of a spell. In Australia, these risks systematically decline through to year 8 of an ownership spell; in the UK, they decline over the first three years of any spell, but exhibit no systematic trend in later years.

These impressions are both qualified and intensified if we take into account the fact that the majority of ownership spells in the sample are left-censored (they began before the start of the study, prior to 2001, and thus largely represent the trajectories of established owners). ${ }^{2}$ A snapshot of what happens closer to the edges of ownership, where spells are populated by more recent housing market entrants, can be achieved by omitting the left-censored spells (see Fichman 1989), as indicated in Table 2. The resulting hazard rates (for spells starting between and including 2002 and 2010) are shown in Figure 2. The hazard rates now are notably higher (at least twice as high for Australia; five times greater in the UK), and the gap between jurisdictions is less wide. The risks are still highest in the early years; they still reduce over time - though not consistently. It is striking, however that, while Australian probabilities of exit fall from $14.1 \%$ in year 1 to $5.8 \%$ in year 7 , for a randomly selected Australian entering home ownership between 2002 and 2010 the chances of 'survival' beyond year 7 are only 59\%. The chances of 'survival' are a little higher at $68 \%$ in the UK. The edges of ownership, it seems, are defined by time as well as space.

\section{[Table 2]}

\section{[Figure 2]}

Taken together, these descriptive measures exhibit a number of features that bear further consideration. First, why are exit rates overall so low in both countries, despite the degree of financial stress to which households were subject during the GFC?. Second, recent entrants are especially vulnerable to exit, but why; what else characterises those who are close to the edges of ownership? Finally, why do UK households appear to be less vulnerable to exit than their Australian counterparts, given the greater buoyancy of the Australian economy through the credit crisis? BHPS, Understanding Society and HILDA are rich data sets,

\footnotetext{
${ }^{2}$ Only $1907(28 \%)$ of Australian ownership spells and $674(11 \%)$ of those in the UK are not left-censored. 6
} 
containing a number of variables that can be tracked over time to cast light on these questions. To exploit these data more fully we turn next to a modelling exercise.

\section{Negotiating the edges of ownership: risks and their effects}

To differentiate between ongoing owners and those vulnerable to exit, and thus addressing the second of the questions listed above, we model transitions from owner-occupied housing into rental housing, defining it as an event that terminates a 'career' (or spell) in home ownership. We include four groups of independent variables. First, we tap into the accumulation of human capital and participation in labour markets (age, qualifications, income, and employment). Second, we include variables linked to biographical shifts or disruptions (household formation and dissolution, changes in health).

Third, there are measures of indebtedness or financial stress comprising not only a traditional measure - loan-to-value ratios ${ }^{3}$ - but also two little-used but increasingly important financial behaviours, 'equity extraction' and 'in situ equity borrowing'. Equity extraction is a straightforward measure of the equity released when households trade on within owner occupation, exchanging one property for another and releasing funds in the process. In situ equity borrowing is more common, and in some senses more interesting in that, throughout the first decade of the $21^{\text {st }}$ century, most mortgage products in Australia and the UK included a facility enabling households to 'borrow up' as well as 'pay down' their loan, without moving home or re-mortgaging. This has some features in common with US practice of 'cash-out refinance, and with that country's 'home equity line of credit' products, but it does not have the lumpiness of the 'cash out' transactions nor the costs and inflexibilities of the refinance package.

Equity borrowing in Australia and the UK is effectively about using a facility already built into mortgage products to revolutionise households' financial behaviours, enabling them to roll housing wealth into day-to-day calculations around savings, spending and debt. We have shown elsewhere that this is both the dominant mode of housing equity withdrawal in the UK and Australia (Ong et al. 2013), and also a resource of last resort to meet pressing spending needs (Wood, Smith et al. 2013). So, for the purposes of this paper, equity borrowing enters the model as a form of financial buffer, that is both an indicator of financial stress and a possibly risky means of mitigating it (Benito 2007). We add to this a measure of equity extracted (either as cash, or via borrowing) during residential relocation within owner

\footnotetext{
${ }^{3}$ The common alternative, debt-to-income ratio, is excluded due to collinearity. 
occupation, something which again, intuitively, suggests a household is seeking to overcome liquidity constraints.

Finally, we add variables to capture the impact of the global financial crisis (in the form of post-crisis calendar years). Table 3 lists variable definitions and units of measurement as employed in model estimation.

[Table 3]

To test the effects of these variables, we estimate a discrete-time hazard model with a specification that allows the risk of a move out of home ownership to vary over the course of a spell, while also permitting predictors to determine risk. The logistic regression routine described below, when applied to a pool of observations (for each person for each year) in the panel data sets, provides maximum likelihood estimates of the discrete time hazard model.

The sample size is large, and the model correspondingly robust. In the British dataset there are 46746 observations, of which 471 (1\%) are episodes in which an exit from home ownership is recorded. In the Australian data there are marginally fewer person-period observations $(33,989)$, however because baseline hazard rates are higher there are 877 episodes (2.6\% of the sample) in which owners depart home ownership, close to double the number in Britain.

The discrete time hazard model can be written as:

$$
\log i t h_{i j}(t)=\left[\alpha_{1} D_{1}+\alpha_{2} D_{2}+\ldots \ldots+\alpha_{J} D_{J}\right]+\left[\beta_{1} X_{1}+\beta_{2} X_{2}+\ldots \ldots \ldots+\beta_{P} X_{P}\right]
$$

On the left-hand side (the probability of exit or not) we have a transformed version of the hazard- $\mathrm{h}_{\mathrm{ij}}(\mathrm{t})$-where i denotes the individual, $\mathrm{j}$ the time interval/period and $h_{i j}$ is the conditional probability at $\mathrm{j}$. The right-hand side has two components: $D_{1}$ to $D_{J}$ are $\mathrm{J}$ time indicators. The alphas describe how the hazard changes as spells lengthen. As a group, these alphas represent the baseline logit hazard function when all the predictors $X_{1}$ to $X_{P}$ are set equal to 0 . The estimated alphas tell us whether risk is constant, declining or increasing over time for the baseline group, and hence whether duration dependence is absent, negative or positive. When we add or omit Xs the definition of the baseline group changes.

The second group of variables on the right-hand side is the biographical, financial and 
contextual characteristics that are expected either to shepherd households into mainstream ownership, or to precipitate departures from home ownership. The betas when multiplied by unit differences in their respective variables shift the baseline function, controlling for the effects of other variables in the model. The betas therefore act as a shift parameter, which means that their impact on the logit hazard is constant in all time periods. The $X_{1}$ to $X_{P}$ predictors can take on two forms-dichotomous and continuous. The raw parameter estimates (co-efficients) therefore have little intuitive appeal. A common strategy is to transform parameter estimates into easier-to-interpret odds ratios and we follow this convention. ${ }^{4}$

Table 4 summarises the key characteristics for each country of those persons in continuing and interrupted ownership careers. It is impossible to know from summary statistics of this kind whether and to what extent these variables are independently associated with the risk of exit. But it is worth noting that in both countries leavers are younger than ongoing owners, that marriage reduces the likelihood of exit, that being single, divorced, separated and (in the UK widowed) raises it, and that in the UK alone health appears to have a protective effect. Employment and income variables are significant markers of difference between ongoing owners and leavers in the UK though the effects vary between measures. Indebtedness, as measured by loan to value ratios, elevates the risk of exit in both jurisdictions, while equity borrowing appears to mitigate such risks. To test these first impressions, we turn to the fitted models (Table 5).

\section{[Table 4]}

The models set out below contain 21 variables whose impact on the likelihood of exit from ownership is statistically significant for Australia and 18 for the UK. Together they explain over two-thirds of the variance in the exit data in both countries, and overall both models are a relatively good fit. For the purposes of this section of the paper, there are seven interesting features.

\section{[Table 5]}

First, the model confirms for both countries the importance of employment for the

\footnotetext{
${ }^{4}$ So, for a categorical variable, the effects of included categories (divorced and separated, for example) are measured relative to the omitted category (marrieds, for example). A value less than one means that the risks of exit are reduced proportionately relative to the omitted (e.g. by half if the value is 0.5 ); a value greater than one signals that risks are similarly elevated. 
sustainability of ownership. Those in full-time employment have a much lower likelihood of exiting ownership - $62 \%$ lower in Australia, 56\% lower in the UK - than those who are unemployed or not in the labour force. This is entirely expected: housing systems centred on mortgaged owner occupation depend for their viability on households having secure, regular, income streams to service their loans. Once we control for other personal characteristics we find that income levels are also important in shaping the chances of exit: for every additional AU $\$ 1 \mathrm{k}$ income, Australian households risks of exit reduce by $1 \%$; for every increment of $£ 1 \mathrm{k}$ in the UK, there is a $5 \%$ reduction of risk. To elaborate, by setting all continuous variables at their mean values, and choosing the reference category for binary variables, we estimate based on the coefficients reported in the table that for a younger person, a one standard deviation increase in income lowers the risk of exit from $22 \%$ to $16 \%$ in Australia and from $6 \%$ to $3 \%$ in Britain. The only human capital variable that operates differently across the two countries is education: in the UK, but not in Australia, having a tertiary qualification significantly and substantially reduces the risk of exit (by as much as $26 \%$ compared to not having this level of education).

Second, the analysis underlines the risks to ownership of the biographical disruption associated with separation or divorce. These risks are the highest identified in the model, in both countries. All else equal, the likelihood of loss of ownership among those who are separated or divorced is nearly three and two-thirds times higher than for married couples in Australia, and over two and three-quarters times higher in the UK. Again, we can illustrate the point with some more specific predicted hazards estimates based on the coefficients reported in table 5 . Setting continuous variables to their mean, and selecting the reference categories as above, if we take, on the one hand, a young (under 35 years) divorced or separated person in the sixth year of an ownership spell, the probability of exit is $53 \%$ in Australia and $13 \%$ in Britain. If, on the other hand, we take a married person with one child, the Australian model estimates the risk of departure from home ownership as $9 \%$, and the British even lower at $5 \%$. So the differences are stark, highlighting both the risks of separation and the protective effect of being married, particularly if children are present.

It is tempting to link this to the scale economies of shared costs and the boost of dual incomes, but we note that the contrast is primarily between being married and being divorced or separated. When other factors are controlled for, the risk of exit among never married singles is not significantly different from that of married couples, and the risks to ongoing ownership of widowhood is only elevated among Australians. So there is more to say about the relationship between household formation and dissolution and the sustainability of owner occupation. 
Third, while age has a similarly independent, cumulative and protective effect in both countries, the modelling exercise suggests that being in anything other than excellent health is risky across the board, but (contrary to the indication in the descriptives presented earlier) especially in Britain. British households who are not in the best of health are almost twice as likely as those who are well, to fall out of ownership. In contrast the likelihood of exit among their Australian counterparts is elevated (relative to those in excellent health) by just $20 \%$. This health effect is a first pointer to the importance of institutional differences between the two jurisdications, which we pick up on later. It may reflect the effect of the larger social housing sector in Britain, whose needs-based allocation systems have traditionally prioritised those with adverse health conditions (Smith 1990; Smith et al. 1997). In fact closer inspection of the data shows that $21 \%$ of UK leavers land in the social rented sector ${ }^{5}$, and among those who enter the social housing sector, $95 \%$ are not in the best of health.

Next, we consider the effects of debt. As might be expected, the risk of exit increases in line with loan-to-values ratios, by around half a per cent for every one per cent increase in the ratio in both countries (slightly more in Australia, where the effect is unambiguously statistically significant; it is marginally significant for the UK). There is a hint here that financial stress is associated with the loss of home ownership, and this is confirmed elsewhere, where we compare ongoing owners with leavers on a variety of measures and show leavers to be in a financially precarious position (Wood, Parkinson et al. 2013). In Australia, compared to ongoing owners, leavers experience more than twice as many episodes of failure to pay utility bills on time, more than twice as many waves in which they could not raise money in an emergency, nearly three times as many instances of having to turn to friends and family for cash, and over four times the likelihood of not being able to meet their housing costs. In the UK, leavers spend more than twice as much time as owners unable to afford an annual holiday, having difficulty replacing worn out furniture, being unable to entertain family and friends at home, and having difficulty in paying for housing.

Fifth, some complexity is added to this picture by the finding that, in both countries, equity borrowing and equity extraction are (independently) associated with a significant and substantial reduction in the risks of exit (for equity borrowing, by over a third in Australia and half in the UK). This is, in one sense, counter-intuitive, since we know from previous work that equity borrowing in these contexts is associated with pressing spending needs and forms a financial buffer for households with few other financial resources (Wood, Smith et al.

\footnotetext{
${ }^{5}$ In Australia where social housing is a residual tenure, only $0.4 \%$ of leavers enter social housing. 
2013). We also suspect, in line with other commentators, that, as debts accumulate and resources run out, there is a cascade effect from equity borrowing, through trading down, to selling up (Ong et al. 2013). So a protective effect is unexpected.

This effect might, however, be explained if we regard equity exchange at the edges of ownership as a sometimes-effective tactic enabling households to roll housing wealth into their attempts to manage adverse shocks and bridge financial gaps. Equity borrowing or trading down might thus begin from a relatively secure footing in owner occupation, and operate successfully as a financial buffer for a while, or even for the long term in the absence of future financial shocks (Wood, Parkinson et al. 2013). That bridging effect might indeed be dominating the data reported here. A closer look, however, indicates that although leavers engage in equity borrowing less frequently than ongoing owners, it is more likely to lead to a net worsening in their debt position over time (ie they are less likely to balance equity extraction in one year with equity injection in another), and those whose debt position worsens over the study period are four times as likely as those whose position is static or improves to trade on (even though this will later lead them to exit ownership). So where the protective effect of equity extraction fails (among those who engage in equity borrowing but fail to sustain home ownership), it appears to have particularly adverse consequences on households' financial and wider wellbeing. We have argued before (Parkinson et al. 2009) that equity borrowing functions both as a convenient, low cost source of funds for the better off, and as a risky option for those with limited funds and pressing spending needs. The analysis here highlights the ease with which households might drift from one circumstance to the other.

Sixth, the model includes calendar year as a measure of the effects of the GFC on the sustainability of home ownership. In the UK, but not Australia, in every post-GFC year the odds of exit are more or less doubled compared to the preceding credit-rich years (though we attach caution to the 2009 effect because of the difficulty of linking BHPS and US). This is a result we might have expected, since the downturn in the British housing market triggered by the Global Financial Crisis was steeper than that in Australia. To elaborate, between 2007 and 2009, UK nominal house prices plunged $8.8 \%$ before a recovery in 2010 when house prices increased by $7.2 \%$ but still remained below their levels in 2007 . On the other hand, Australian house prices were flat in years 2007-09 before accelerating again in 2010 until they were $20 \%$ higher than in 2007 . The broader macroeconomic picture was also weaker in the UK; recession in the UK economy resulted in real GDP falling by 4.9 percentage points between years 2007 and 2009, while the Australian economy continued to 'post gains' with real GDP growth of 3.7 percentage points over the same period (OECD, 12 
2015). All this suggests that British households might be hardest hit by recession, and in that sense, the recession effect in the model seems plausible.

There are, nevertheless, some mitigating factors which we might have expected to dampen the GFC effect in the UK, compared to Australia. For example, in the UK mortgage interest rates tumbled in response to the financial chaos, offering some protection, at least to those with variable rate mortgage contracts. In 2006 , variable rates averaged $6.5 \%$, but over the three-year period 2007-10 the average rate was only 5.6\% (and individual rates were often much lower). These lower rates eased the housing cost burden of leveraged UK homebuyers in ways not available to their Australian counterparts, where the mean mortgage interest rate was $7.6 \%$ throughout the period $2006-10 .{ }^{6}$ Despite these different interest rate profiles, and even though the proportion of Australian mortgagors who reported difficulties meeting payments was higher than in Britain in 2006 (4.6\% compared to 1\%), distress rose in the UK (to 5.3\%) towards 2009 while remaining steady in Australia. Nevertheless, nearly 1 in 10 (9.2\%) of Australians who were mortgagors in 2006 transitioned out of home ownership between 2007 and 2009, compared with just 2.3\% of their British counterparts. This suggests that other factors - possibly institutional differences - are having a mediating effect. We turn to this shortly.

Finally, we note that the 'year of spell' estimates in the hazard model confirm the independent effects of time spent in ownership on the likelihood of exit from it. There is a protective effect associated with length of spell that is much more marked in the UK than in Australia, and is independent of any of the variables we have discussed so far. This focuses attention squarely on the substantially greater likelihood across the board of Australians slipping out of ownership. So having spent this section highlighting some of the common predictors of exiting ownership in the two case study nations, we turn in the final section of the paper to the third set of questions highlighted earlier, namely how to account for some key differences between jurisdictions that are, at first glance, counter-intuitive.

\section{Institutions matter}

It is only in the last decade that the housing economy has finally taken centre stage in a growing body of work among economists, political scientists, sociologists and geographers concerned with the relationship between global financial flows and domestic or local economies. While a few commentators recognise that geography matters (Aalbers, 2009;

\footnotetext{
${ }^{6}$ Interest rate calculations for the UK were based on monthly standard variable interest rates from the Bank of England Statistical Interactive Database <http://www.bankofengland.co.uk/boeapps/iadb/>.
} 
Dymski, 2009; Martin, 2011), more commonly the focus is on an internationalising arena whose impulse is to make every thing 'the same' (and therefore more tradeable) (Bryan \& Rafferty 2006; O'Brien 1990). The shape of the UK and Australian housing finance systems bear the imprint of this: both are ownership-centred, both ventured into mortgage backed bonds, both have complete mortgage markets, both had a product range sufficiently developed to nurture equity borrowing, and so on. So it is not surprising that both financial behaviours and housing outcomes bear the similarities which the models reported earlier have identified.

However, there are also signals in the data which suggest that the effects of internationalising mortgage markets might be quite critically mediated by institutional differences. We can look more closely at this question by calibrating each country's hazard model at the typical personal characteristics of one country's sample of 'at risk' owners. This exercise simulates the chances of a typical Australian (or British) owner moving out of ownership in each country. It takes differences in personal characteristics and attributes 'out of the equation' and evaluates whether there are any remaining differences in the probability of exiting home ownership. If differences in the variables that we know to have an effect on the probability of exit have been largely eliminated (or effectively controlled for) and yet differences persist, then we can attribute these to factors external to individuals which differ between jurisdictions.

To that end, we calculate the mean characteristics of each person over the period 20012010 for Australia and 2001-2009/10 for the UK. So for instance, a key binary personal characteristic is whether a person has excellent health or not in each wave. We calculate the percentage of waves in which a person has excellent health, and compute the average across the entire sample to arrive at a representative excellent health status for homeowners in that country. A similar procedure is used for continuous variables such as income; we simply calculate each person's mean income across the study timeframe, then average across the full sample to arrive at a value for income that is typical among that country's owners. ${ }^{7}$

\footnotetext{
${ }^{7}$ Note that while it makes statistical sense (for the purposes of identifying institutional effects) to define the average home owner by calculating the mean of each of a range of personal characteristics, it does not follow that these add up substantively into a composite household in either country. For example, if the average age in the sample is (say) 54 years and the average income is (say) $\$ 90,000$, these would be the correct figures to use for the exercise defined in the text but would not imply that the typical homeowner is 54 years of age with income of $\$ 90,000$. In fact, if we looked at the age of people/owners with incomes of roughly $\$ 90,000$ we might find that they are typically in their mid-40s not their mid-50s, because the age distribution is strongly skewed to higher ages where incomes are lower, and earnings peak for people in their $40 \mathrm{~s}$
} 
The hazard models are calibrated by taking a representative person from Australia, and then predicting the probability of exit in each year using the estimated coefficients from the Australian model. The same representative person's predicted probabilities of exit under UK conditions are evaluated by applying the UK model's estimated coefficients (see table 6a). For validation purposes, the same exercise is repeated in reverse by taking a representative person from the UK and comparing the predicted probability of exit under UK and Australian settings - see table $6 b)^{8}$. A predicted conditional probability is calculated for each year of the spell ${ }^{9}$.

On conducting the calibrations at mean Australian characteristics we find that predicted probabilities of exit remain lower in the UK. The different risk profiles are especially well illustrated by survival rates; at year 8 a survival rate of $76 \%$ in the Australian housing system is well below the $90 \%$ rate in Britain's housing system. On reversing the calibration by using mean British characteristics, predicted values confirm a conclusion that the more fluid Australian interface between ownership and renting is due to differences in variables other than personal characteristics.

\section{[Table 6]}

What are these important inter-country differences? The findings of the modelling exercise have turned our attention to two institutional factors in particular which might disproportionately draw marginal Australian owners into the rented sector, while propping up the ownership ideals of their British counterparts. Whether this is, in the end, fortunate or not for households in either country is a moot point and one we conclude with.

First, and most obviously, the rental sectors of the two countries are somewhat different in size, character and maturity. Notwithstanding some convergence over the decade to 2010 (Community and Local Government Committee 2013; Hulse et al. 2012) they therefore appear to have a different function at the edges of ownership. About 25 per cent of Australian households are private renters creeping slowly up from 22 per cent across the study period ${ }^{10}$. The British private rented sector, in contrast, expanded rapidly in those years,

\footnotetext{
${ }^{8}$ Income is reported in the currency of the country of residence. Australians' incomes must be converted into UK pounds when we simulate the predicted probability of exit for a representative Australian under UK institutional settings (and vice versa when we predict the probabilities of the British sample under Australian settings). Currency conversions are conducted using the dollar-sterling exchange rates from the Reserve Bank of Australia. ${ }^{9}$ The calendar year indicator variables have been set equal to zero.

${ }^{10}$ Australian Bureau of Statistics 2015, Housing occupancy and costs, 2013-14 (cat. no. 4130.0), viewed 27 October 2015, http://www.abs.gov.au/AUSSTATS/abs@.nsf/DetailsPage/4130.02013-14?OpenDocument
} 
from a low base of 16 per cent to around 19 per cent by $2010^{11}$. It seems plausible to argue that the higher likelihood of exit from ownership in Australia across the 2000s reflects the greater ability of the larger unregulated Australian private rental sector in 'oiling the wheels' between renting and ownership. That is, the size, geography and diversity of the Australian private rented sector may make it relatively easy for households to adjust housing costs to incomes by moving before mortgage stress becomes excessive. Arguably, therefore, the sector may perform a risk management role, offering temporary, relatively easily accessible, refuge for those on the edges of home ownership. It might also provide a vantage point, or holding position, for movers who wish to screen opportunities to buy at their destination. Whatever the reason, Australian leavers exit sooner and in better financial shape than their British counterparts, and elsewhere we show that a proportion of them are therefore better placed to return at a later date (Wood, Smith et al. 2013).

Britain's private rental market is not only relatively small; it is not sufficiently diverse to perform the same role. In contrast, the UK's social housing sector is comparatively large (accommodating perhaps 17 per cent of British households, compared to less than 5 per cent in Australia) but may be less universally useful at the edges of ownership. This is because the needs-based allocation systems used to suspend the market mechanism do not prioritise those who exit owner occupation simply for financial reasons. So while social housing does provide a 'soft landing' and potentially permanent sanctuary for those forced out of owner occupation by extreme financial adversity, it only does so if financial stress is coupled with pressing social (such as health) needs (a property first highlighted in Smith 1990). Otherwise, the pressure is to stay until all options are exhausted. The British rental sector does not therefore offer the same fluidity of movement between tenures that seems characteristic of the Australian rental sector. As a result, exit from ownership may be easier for, and more appealing to, Australian than UK households.

Second there are differences in the two countries' social security systems which may compound this differential effect. Historically, British home owners with particular financial needs (such as the loss of all earned income) have been eligible for what is now known as support for mortgage interest (SMI). There is no such safety net for mortgagors in Australia. According to Wilcox and Pawson (2011) the number of British recipients peaked at over half a million in 1993, and still numbered 200,000 in 2011 , despite a succession of curbs

11 Office for National Statistics 2013, Home ownership and renting in England and Wales - detailed characteristics, viewed 22 October 2015, http://www.ons.gov.uk/ons/rel/ census/2011-census/detailedcharacteristics-on-housing-for-local-authoritiesin-england-and-wales/short-story-on-detailed-characteristics.html (accessed 21/7/15). 
introduced between 1987 and 1995. Furthermore, at the time the British housing market was hit by the GFC, although SMI had previously been subject to a ceiling of $£ 100,000$, in order to support homebuyers in distress this was doubled to $£ 200000$ in January 2009.

Conditional on completing a waiting period that was temporarily reduced from 38 weeks to 13 weeks in January 2009, SMI now continues indefinitely as long as the claimant remains out of work (Stephens 2011). Lender forbearance has also been a major factor in preventing the translation of arrears into possessions in the current UK housing cycle (Finney \& Kempson 2009).

\section{Conclusion}

Using household panel surveys from Australia and the UK, this paper has offered a perspective on precarious home ownership that is both original and, in some senses, unexpected. First, we showed that across the 2000s rates of exit from owner-occupation were surprisingly low (especially compared with, for example, some regions of the USA). This is partly related to similarities in the mortgage markets of the two countries: mortgage interest rates fell to very low levels during this decade; mortgages are full recourse in UK and Australia so that home buyers in UK and Australia are less likely to default; and critically - both countries have complete, comparatively well regulated mortgage markets that support equity borrowing, which in turn can bridge income dips, at least for a while. Against this backdrop it is likely that most home owners sacrifice other spending and prioritise mortgage payments in order to keep a foot on the housing ladder. As a result, while the macro-economic environment of the later 2000s may have pushed households to the very edges of ownership, the majority remained in the sector.

Secondly, we used a modelling exercise to identify some of the main risks facing home occupiers at the edges of ownership, where low incomes, loss of employment, relationship breakdown, and escalating debt can propel recent entrants very rapidly out of the housing market. Those able to hold on for more than a year have a better chance of consolidating their position and moving towards the mainstream, especially if they have sufficient income and home equity to use equity borrowing as a financial buffer. Those unable to use this to bridge their funding gap successfully, however, are in the riskiest position of all.

Finally, we showed that because of some important institutional differences, those on the edges of Australian and British home ownership can respond very differently to the shocks of the early $21^{\text {st }}$ century. In Australia, the absence of public benefits for mortgagors, together with a large and flexible private rental housing sector, may have encouraged owners to exit 17 
early in anticipation of growing financial pressures. In that sense, the Australian housing system better accommodates those who wish to exchange the costs of owning for those of renting and are willing to move home in order to do so. In contrast, while British mortgagors' payment difficulties climbed to levels higher than those in Australia, support for mortgage interest, the extent of lender forbearance, and limited opportunities to use the rental sector to adjust to financial pressures, appear to have kept British exit rates from home ownership at relatively low levels over the study period.

Whether, in the long run, either 'solution' is satisfactory is a topic that should be more widely aired in the policy community. There is, for example, considerable interest in the UK in the intermediate tenures of shared ownership and equity share (Monk and Whitehead 2010), which, if provided at scale could offer an escape valve for financially stretched whole-home owners, perhaps improving on the diversity offered by the Australian private rental sector. On the other hand, if households in either society have the need or appetite routinely to swap the costs of owning for those of renting or shared ownership (as the evidence of 'churn' presented earlier suggests they do), then it must be time to consider the policy relevance of a suite of financial instruments designed to enable this (Smith et al. 2013; Smith 2015; Mian and Sufi 2014). Collectively known as equity finance, these might, if suitably packaged and built into policy, deliver creative solutions to households without incurring the massive transactions costs, and domestic upheaval, of physical residential property exchange.

\section{References}

Aalbers, M. (2009), The sociology and geography of mortgage markets: reflections on the crisis, International Journal of Urban and Regional Research, 33, 281-290.

Beer, A. and Faulkner, D. (2009), $21^{\text {st }}$ Century Housing Careers and Australia's Housing Future, Final Report, Melbourne: Australian Housing and Urban Research Institute.

Beer, A., Bentley, R., Baker, E., Mason, K., Mallett, S., Kavanagh, A. and LaMontagne, T/ (2015) Neoliberalism, economic restructuring and policy change: Precarious housing and precarious employment in Autralia. Urban Studies. DOI:

$10.1177 / 0042098015596922$

Benito, A. (2007) Housing equity as a buffer: evidence from UK households. Working Paper No. 324, Bank of England, London

Berger, L. M., Collins, J. M. and Smeeding, T. M. (2015) Exiting or retaining owner occupied housing in the United States 1999-2009. How do social programs matter? Children 
and Youth Services Review 57, 112-126

Bryan, D. and Rafferty, M. (2006), Financial derivatives: the new gold?, Competition and Change, 10, 265-282.

Burd-Sharps, S and Rasch, R (2015) Impact of the US housing crisis on the racial wealth gap across generations. SSRC/American Civil Liberties Union

Clark, W. A. V., Deurloo, M. C. and Dieleman, F. M. (2003), Housing Careers in the United States, 1968-'93: Modelling the Sequencing of Housing States. Urban Studies, Vol. 40, No. 1: $143-160$

Clark W.A.V. (2013): The aftermath of the general financial crisis for the ownership society: what happened to low-income homeowners in the US?, International Journal of Housing Policy, OI:10.1080/14616718.2013.796811

Community and Local Government Committee (2013) The Private Rented Sector. First report of session 2013-14. House of Commons. London: The Stationery Office Dymski, G. (2009), The global financial customer and the spatiality of exclusion after the 'End of Geography', Cambridge Journal of Regions, Economy and Society, 2, 267286.

Fichman, M. (1989), Attendance makes the heart grow fonder: A hazard rate approach to modelling attendance, Journal of Applied Psychology, 74, 325-335.

Finney, A. and Kempson, H. (2009), Consumer Purchasing and Outcomes Survey, UK Financial Services Authority.

Forrest, R. \& Yip, N. M (Eds.) (2011) Housing markets and the global financial crisis: the uneven impact on households. Cheltenham: Edward Elgar

Hulse, K., Burke, T., Ralston, L. and Stone, W. (2012) The Australian private rental sector: changes and challenges. AHURI positioning paper 149. Melbourne: Australian Housing and Research Institute.

Langley, P. (2008), Sub-prime mortgage lending: a cultural economy, Economy and Society, 37(4), 469-494.

Laurie, H. (2010), Continuity and innovation in the Design of Understanding Society: The UK household longitudinal study, Working Paper series no.2010-02, Institute for Social and Economic Research, University of Essex.

Martin, R. (2011), The local geographies of the financial crisis: from the housing bubble to economic recession and beyond, Journal of Economic Geography, 11, 587-618.

Mian, A. and Sufi, A. (2014), House of Debt, Chicago: University of Chicago Press.

Monk, S. and Whitehead, C. M. E. (eds) (2010), Making Housing More Affordable: The Role of Intermediate Tenures, Chichester: Wiley-Blackwell. 
O'Brien, R. (1990), Global Financial Integration: The End of Geography, London: Pinter. OECD (2015), Economic Outlook Annex Tables, Available:

http://www.oecd.org/eco/outlook/economicoutlookannextables.htm (accessed 18/10/2015).

Ong, R., Parkinson, S., Searle, B.A., Smith, S.J. and Wood, G. (2013), Channels from Housing Wealth to Consumption, Housing Studies, 28, 1012-1036.

Parkinson, S., Searle, B.A., Smith, S.J., Stoakes, A. and Wood, G. (2009), Mortgage equity withdrawal in Australia and Britain: Towards a wealth-fare state?, European Journal of Housing Policy, 9, 363-387.

Pickles, A. and Davies, R. (1986), Household Factors and Discrimination in Housing Consumption: Further Developments in the Analysis of Tenure Choice within Housing Careers. Regional Science and Urban Economics, Vol 16, No. 4, 493-517.

Pickles, A. and Davies, R.(1985), The Longitudinal Analysis of Housing Careers, Journal of Regional Science, Vol 25, No. 1:85-101.

Scanlon, K. and Whitehead, C.M.E. (2004), International Trends in Housing Tenure and Mortgage Finance, Council of Mortgage Lenders, London.

Singer, J.D. and Willett, J.B. (2003), Applied Longitudinal Data Analysis: Modelling Change and Event Occurrence, Oxford: Oxford University Press.

Stephens, M. (2011), Tackling Housing Market Volatility in the UK, May, Joseph Rowntree Foundation.

Smith, S. J. (1990), Health status and the housing system, Social Science and Medicine, 31, 753-762.

Smith, S.J. (2013), Crisis and innovation in the housing economy: A tale of three markets, in Haliossis, M. (ed) (2013), Financial Innovation - Too Much or Too Little?, Cambridge, Mass: MIT Press.

Smith, S. J. (2015) Owner occupation: at home in a spatial, financial paradox. International Journal of Housing Policy 15: 61-83

Smith, S.J., Alexander, A. and Easterlow, D. (1997), Rehousing as a health intervention: Miracle or mirage?, Health and Place, 5, 203-216.

Smith, S.J., Whitehead, C.M.E. and Williams P. (2013), A Role for Equity Finance in UK Housing Markets, Joseph Rowntree Foundation.

Turner, T. M. and Smith, M. (2009) Exits from homeownership: the effects of race, ethnicity and income. Journal of Regional Science 49: 1-32

Wachter, S., Russo, K. and Hershakff, J. (2006), Subprime Lending: Neighbourhood Patterns over Time in US Cities, Institute for Law and Economics, Research Paper 06-19, University of Pennsylvania. 
Whitehead, C.M.E. and Yates, J. (2010), Is there a role for shared equity products in twentyfirst century housing? Experience in Australia and the UK, in Smith, S.J. and Searle, B.A. (eds) (2010), The Blackwell Companion to the Economics of Housing: The Housing Wealth of Nations, Chichester: Wiley-Blackwell, pp. 481-498.

Wilcox, S. and Pawson, H. (eds) (2011), UK Housing Review 2010-2011, Centre for Housing Policy, York, Available at www.york.ac.uk/res/ukhr/ukhr1011/compendium.htm

Wood, G. and Ong, R. (2011), Factors shaping the dynamics of housing affordability in Australia 2001-2006, Housing Studies, Special Issue: Affordable Housing and Housing Affordability, 26:7-8, 1105-1127

Wood, G., Ong, R. and Cigdem, M. (2014), Housing Affordability Dynamics: New Insights from the Last Decade, Final Report No. 233, Australian Housing and Urban Research Institute, Melbourne

Wood, G., Parkinson, S., Searle, B.A. and Smith, S.J. (2013), Motivations for equity borrowing: A welfare switching effect, Urban Studies, 50, 2588-2607.

Wood, G., Smith, S.J., Ong, R. and Cigdem, M. (2013), The Edges of Home Ownership, Final Report, Melbourne: Australian Housing and Urban Research Institute. 
Table 1: Spells in home ownership that were ongoing in 2001 or began in the calendar years 2002 to 2010 , sample estimates ${ }^{a}$

\section{(a) Australia}

\begin{tabular}{|c|c|c|c|c|c|c|}
\hline $\begin{array}{l}\text { Year of } \\
\text { spell } \\
(t)\end{array}$ & $\begin{array}{l}\text { Time } \\
\text { interval }\end{array}$ & $\begin{array}{l}\text { Number of } \\
\text { spells at } \\
\text { start of year } \\
(Y)\end{array}$ & $\begin{array}{l}\text { Number exiting } \\
\text { home ownership } \\
\text { during the year } \\
(N)\end{array}$ & $\begin{array}{l}\text { Spells } \\
\text { censored at } \\
\text { the end of } \\
\text { year }\end{array}$ & $\begin{array}{l}\text { Hazard rate } \\
h_{t}=N_{t} / Y_{t}\end{array}$ & $\begin{array}{l}\text { Survival rate } \\
S_{t}=S_{t-1}\left(1-h_{t}\right)\end{array}$ \\
\hline 0 & {$[0,1)$} & 6,830 & 0 & 182 & & 1.00 \\
\hline 1 & {$[1,2)$} & 6,648 & 427 & 143 & 0.06 & 0.94 \\
\hline 2 & {$[2,3)$} & 6,078 & 234 & 157 & 0.04 & 0.90 \\
\hline 3 & {$[3,4)$} & 5,687 & 193 & 146 & 0.03 & 0.87 \\
\hline 4 & {$[4,5)$} & 5,348 & 165 & 151 & 0.03 & 0.84 \\
\hline 5 & {$[5,6)$} & 5,032 & 136 & 137 & 0.03 & 0.82 \\
\hline 6 & {$[6,7)$} & 4,759 & 90 & 134 & 0.02 & 0.80 \\
\hline 7 & {$[7,8)$} & 4,535 & 81 & 142 & 0.02 & 0.79 \\
\hline 8 & {$[8,9)$} & 4,312 & 79 & 163 & 0.02 & 0.78 \\
\hline 9 & {$[9,10)$} & 4,070 & 98 & 3,972 & 0.02 & 0.76 \\
\hline Total & & 53,299 & 1,503 & 5,327 & & \\
\hline
\end{tabular}

(b) UK

\begin{tabular}{|l|l|l|l|l|l|l|}
\hline $\begin{array}{l}\text { Year of } \\
\text { spell } \\
(t)\end{array}$ & $\begin{array}{l}\text { Time } \\
\text { interval }\end{array}$ & $\begin{array}{l}\text { Number of } \\
\text { spells at } \\
\text { start of year } \\
(Y)\end{array}$ & $\begin{array}{l}\text { Number exiting } \\
\text { home ownership } \\
\text { during the year } \\
(N)\end{array}$ & $\begin{array}{l}\text { Spells } \\
\text { censored at } \\
\text { the end of } \\
\text { year }\end{array}$ & $\begin{array}{l}\text { Hazard rate } \\
h_{t}=N_{t} / Y_{t}\end{array}$ & $\begin{array}{l}\text { Survival rate } \\
S_{t}=S_{t-1}\left(1-h_{t}\right)\end{array}$ \\
\hline 0 & {$[0,1)$} & 6,091 & 0 & 40 & & \\
1 & {$[1,2)$} & 6,051 & 119 & 38 & 0.02 & 0.98 \\
2 & {$[2,3)$} & 5,894 & 80 & 57 & 0.01 & 0.97 \\
3 & {$[3,4)$} & 5,757 & 65 & 49 & 0.01 & 0.96 \\
4 & {$[4,5)$} & 5,643 & 63 & 58 & 0.01 & 0.95 \\
5 & {$[5,6)$} & 5,522 & 46 & 90 & 0.01 & 0.94 \\
6 & {$[6,7)$} & 5,386 & 57 & 81 & 0.01 & 0.93 \\
7 & {$[7,8)$} & 5,248 & 39 & 101 & 0.01 & 0.92 \\
8 & {$[8,9)$} & 5,108 & 108 & 5,000 & 0.02 & 0.90 \\
NA & {$[9,10)$} & & 500 & & \\
\hline Total & & 50,700 & 577 & 5514 & & \\
\hline
\end{tabular}

Source: Authors' own calculations from the 2001-10 HILDA Survey, 2001-08 BHPS and

Understanding Society wave 2

Note: a. Interviews for Wave 2 of Understanding Society were carried out over an extended period of time. Caution should be taken when interpreting final year and totals of UK. 
Table 2: Spells in home ownership that began in the calendar years 2002 to 2010, sample estimates $^{a}$

(a) Australia

\begin{tabular}{|l|l|l|l|l|l|l|}
\hline $\begin{array}{l}\text { Year } \\
\text { of } \\
\text { spell } \\
(t)\end{array}$ & $\begin{array}{l}\text { Time } \\
\text { interval }\end{array}$ & $\begin{array}{l}\text { Number of } \\
\text { spells } \\
\text { ongoing at } \\
\text { start of year } \\
(Y)\end{array}$ & $\begin{array}{l}\text { Number } \\
\text { exiting home } \\
\text { ownership } \\
\text { during the year } \\
(N)\end{array}$ & $\begin{array}{l}\text { Spells } \\
\text { censored } \\
\text { at the end } \\
\text { of year }\end{array}$ & $\begin{array}{l}\text { Hazard rate } \\
h_{t}=N_{t} / Y_{t}\end{array}$ & $\begin{array}{l}\text { Survival rate } \\
S_{t}=S_{t-1}\left(1-h_{t}\right)\end{array}$ \\
\hline 0 & {$[0,1)$} & 1,907 & 0 & 182 & & 1.00 \\
1 & {$[1,2)$} & 1,725 & 244 & 143 & 0.14 & 0.86 \\
2 & {$[2,3)$} & 1,338 & 101 & 157 & 0.08 & 0.79 \\
3 & {$[3,4)$} & 1,080 & 87 & 146 & 0.08 & 0.73 \\
4 & {$[4,5)$} & 847 & 48 & 151 & 0.06 & 0.69 \\
5 & {$[5,6)$} & 648 & 32 & 137 & 0.05 & 0.65 \\
6 & {$[6,7)$} & 479 & 20 & 134 & 0.04 & 0.63 \\
7 & {$[7,8)$} & 325 & 19 & 142 & 0.06 & 0.59 \\
8 & {$[8,9)$} & 164 & 1 & 163 & 0.01 & 0.59 \\
\hline Total & & 8,513 & 552 & 1,355 & & \\
\hline
\end{tabular}

(b) UK

\begin{tabular}{|c|c|c|c|c|c|c|}
\hline $\begin{array}{l}\text { Year } \\
\text { of } \\
\text { spell } \\
(t)\end{array}$ & $\begin{array}{l}\text { Time } \\
\text { interval }\end{array}$ & $\begin{array}{l}\text { Number of } \\
\text { spells } \\
\text { ongoing at } \\
\text { start of year } \\
\text { (Y) }\end{array}$ & $\begin{array}{l}\text { Number } \\
\text { exiting home } \\
\text { ownership } \\
\text { during the year } \\
\text { (N) }\end{array}$ & $\begin{array}{l}\text { Spells } \\
\text { censored } \\
\text { at the end } \\
\text { of year }\end{array}$ & $\begin{array}{l}\text { Hazard rate } \\
h_{t}=N_{t} / Y_{t}\end{array}$ & $\begin{array}{l}\text { Survival rate } \\
S_{t}=S_{t-1}\left(1-h_{t}\right)\end{array}$ \\
\hline 0 & {$[0,1)$} & 674 & 0 & 40 & & 1.00 \\
\hline 1 & {$[1,2)$} & 634 & 74 & 38 & 0.12 & 0.88 \\
\hline 2 & {$[2,3)$} & 522 & 28 & 57 & 0.05 & 0.84 \\
\hline 3 & {$[3,4)$} & 437 & 22 & 49 & 0.05 & 0.79 \\
\hline 4 & {$[4,5)$} & 366 & 17 & 58 & 0.05 & 0.76 \\
\hline 5 & {$[5,6)$} & 291 & 6 & 90 & 0.02 & 0.74 \\
\hline 6 & {$[6,7)$} & 195 & 7 & 81 & 0.04 & 0.72 \\
\hline 7 & {$[7,8)$} & 107 & 6 & 101 & 0.06 & 0.68 \\
\hline 8 & {$[8,9)$} & & & & & \\
\hline Total & & 3,226 & 160 & 514 & & \\
\hline
\end{tabular}

Source: Authors' own calculations from the 2001-10 HILDA Survey, 2001-08 BHPS and Understanding Society wave 2

Note: a. Interviews for wave 2 of Understanding Society were carried out over an extended period of 
time. Caution should be taken when interpreting final year and totals of UK.

Table 3: Variable definitions and units of measurement

\begin{tabular}{|c|c|c|}
\hline Explanatory variables & Definition & $\begin{array}{l}\text { Binary or } \\
\text { continuous }\end{array}$ \\
\hline Time indicators & $\begin{array}{l}\text { Beginning of home ownership spell (omitted), } \\
\text { First year of spell } \\
\text { Second year of spell } \\
\text { Third year of spell } \\
\text { Fourth year of spell } \\
\text { Fifth year of spell } \\
\text { Sixth year of spell } \\
\text { Seventh year of spell } \\
\text { Eighth year of spell }\end{array}$ & Binary \\
\hline Age bands & $\begin{array}{l}\text { Aged }<35 \text { years (omitted) } \\
\text { Aged } 35-44 \text { years } \\
\text { Aged } 45-54 \text { years } \\
\text { Aged } 55-64 \text { years } \\
\text { Aged } 65 \text { years or over }\end{array}$ & Binary \\
\hline Marital status & $\begin{array}{l}\text { Legally married (omitted) } \\
\text { De facto, i.e. cohabiting but not married } \\
\text { Separated or divorced } \\
\text { Widowed } \\
\text { Single never married }\end{array}$ & Binary \\
\hline Number of children & Number of dependent children & Continuous \\
\hline Self-assessed health & General health is excellent & Binary \\
\hline Highest qualification & Highest qualification is tertiary & Binary \\
\hline Employed & Employed in a full-time or part-time job & Binary \\
\hline $\begin{array}{l}\text { Real equivalised gross } \\
\text { household income }\end{array}$ & $\begin{array}{l}\text { Equivalised gross household income, expressed in } \\
\text { thousands of dollars in } 2010 \text { prices }\end{array}$ & Continuous \\
\hline $\begin{array}{l}\text { Mortgage } \\
\text { indebtedness }\end{array}$ & $\begin{array}{l}\text { Loan-to-value ratio (LVR), defined as mortgage debt as a } \\
\text { proportion of house value averaged over the years of each } \\
\text { home ownership spell, expressed in } \%\end{array}$ & Continuous \\
\hline $\begin{array}{l}\text { Frequency of housing } \\
\text { equity withdrawal }\end{array}$ & $\begin{array}{l}\text { Number of times extracted equity via in situ MEW (equity } \\
\text { borrowing) during home ownership spell } \\
\text { Number of times extracted equity via trading on during } \\
\text { home ownership spell }\end{array}$ & Continuous \\
\hline Calendar year & $\begin{array}{l}\text { Pre-GFC period (omitted) } \\
2007,2008,2009\end{array}$ & Binary \\
\hline
\end{tabular}


Table 4: Personal characteristics of those who remained versus those who left home ownership during 2001-2010, Australia and UK

\begin{tabular}{|c|c|c|c|c|c|c|}
\hline & \multicolumn{3}{|c|}{ Australia } & \multicolumn{3}{|c|}{ UK } \\
\hline & Stayed & Left & All & Stayed & Left & All \\
\hline Mean age (years) & 51.9 & $46.3^{* *}$ & 50.7 & 51.9 & $49.5^{\star *}$ & 51.7 \\
\hline$\%$ waves in age bracket $<35$ & 11.7 & $24.8^{\star \star}$ & 14.5 & 12.1 & $20.4^{* *}$ & 12.8 \\
\hline$\%$ waves in age bracket $35-44$ & 22.0 & $27.4^{* *}$ & 23.2 & 23.5 & $27.0^{*}$ & 23.8 \\
\hline$\%$ waves in age bracket $45-54$ & 24.8 & $20.6^{* *}$ & 23.9 & 21.5 & $18.0^{*}$ & 21.2 \\
\hline$\%$ waves in age bracket $55-64$ & 20.3 & $13.5^{\star \star}$ & 18.9 & 21.2 & $12.9^{* *}$ & 20.5 \\
\hline $\begin{array}{l}\% \text { waves in age bracket } 65 \text { and } \\
\text { over }\end{array}$ & 21.2 & $13.7^{* *}$ & 19.5 & 21.7 & 21.6 & 21.7 \\
\hline$\%$ waves married & 72.1 & $55.7^{* *}$ & 68.5 & 74.5 & $54.4^{* *}$ & 72.7 \\
\hline$\%$ waves defacto & 7.4 & $12.5^{\star *}$ & 8.5 & 7.7 & $14.3^{* *}$ & 8.3 \\
\hline$\%$ waves divorced or separated & 7.6 & $16.4^{* *}$ & 9.5 & 6.2 & $13.6^{* *}$ & 6.8 \\
\hline$\%$ waves widow & 6.1 & 5.3 & 5.9 & 6.5 & $10.0^{* *}$ & 6.8 \\
\hline$\%$ waves single never married & 6.8 & $10.2^{* *}$ & 7.5 & 5.1 & $7.7^{*}$ & 5.3 \\
\hline $\begin{array}{l}\text { Mean number of dependent } \\
\text { children }\end{array}$ & 0.8 & 0.8 & 0.8 & 0.6 & $0.7^{* *}$ & 0.6 \\
\hline$\%$ waves in excellent health & 9.8 & 10.8 & 10.0 & 24.1 & $19.5^{\star *}$ & 23.7 \\
\hline $\begin{array}{l}\% \text { waves with university } \\
\text { qualification }\end{array}$ & 24.1 & 25.2 & 24.3 & 18.1 & 16.1 & 17.9 \\
\hline $\begin{array}{l}\% \text { waves employed } \\
\text { Mean real equivalised gross }\end{array}$ & 64.2 & $68.6^{* *}$ & 65.2 & 58.5 & $52.2^{* *}$ & 58.0 \\
\hline $\begin{array}{l}\text { household income ( } \$ \prime 000 \text { for Aus } \\
\text { and } £^{\prime} 000 \text { for UK) }\end{array}$ & 51.8 & 52.5 & 52.0 & 20.6 & $23.7^{* *}$ & 23.4 \\
\hline Loan-to-value ratio (\%) & 19.9 & $35.2^{* * *}$ & 22.3 & 20.9 & $29.8^{* *}$ & 21.6 \\
\hline $\begin{array}{l}\text { Mean no. of times extracted equity } \\
\text { via in situ MEW during home } \\
\text { ownership spell }\end{array}$ & 1.6 & $1.3^{* * *}$ & 1.6 & 1.2 & $0.7^{* * *}$ & 1.1 \\
\hline $\begin{array}{l}\text { Mean no. of times extracted equity } \\
\text { via trading on during home } \\
\text { ownership spell }\end{array}$ & 0.2 & $0.1^{* *}$ & 0.2 & 0.1 & 0.1 & 0.1 \\
\hline
\end{tabular}

Source: Authors' own calculations from the 2001-10 HILDA Survey, 2001-08 BHPS and

Understanding Society wave 2 .

Differences between those who stayed and left are statistically significant at:

*** $1 \% \quad * * 5 \% \quad * 10 \%$ level 
Table 5: Hazard model parameter estimates of the attributes of sample persons

\begin{tabular}{|c|c|c|c|c|c|c|c|c|}
\hline \multirow[t]{2}{*}{ Explanatory variables $^{a}$} & \multicolumn{4}{|c|}{ Australia } & \multicolumn{4}{|c|}{ UK } \\
\hline & Coef. & $\begin{array}{l}\text { Std. } \\
\text { error }\end{array}$ & Sig. & $\begin{array}{l}\text { Odds } \\
\text { ratio }\end{array}$ & Coef. & $\begin{array}{l}\text { Std. } \\
\text { error }\end{array}$ & Sig. & $\begin{array}{l}\text { Odds } \\
\text { ratio }\end{array}$ \\
\hline First year of spell & 0.713 & 0.103 & 0.000 & 2.041 & -0.052 & 0.152 & 0.731 & 0.949 \\
\hline Second year of spell & 0.266 & 0.121 & 0.028 & 1.304 & -0.152 & 0.162 & 0.350 & 0.859 \\
\hline Third year of spell & 0.371 & 0.126 & 0.003 & 1.449 & -0.082 & 0.170 & 0.629 & 0.921 \\
\hline Fourth year of spell & 0.407 & 0.133 & 0.002 & 1.502 & -0.188 & 0.181 & 0.300 & 0.829 \\
\hline Fifth year of spell & 0.326 & 0.146 & 0.025 & 1.386 & -0.460 & 0.203 & 0.023 & 0.631 \\
\hline Sixth year of spell & 0.099 & 0.220 & 0.654 & 1.104 & -0.552 & 0.274 & 0.044 & 0.576 \\
\hline Seventh year of spell & 0.257 & 0.248 & 0.300 & 1.293 & -1.074 & 0.315 & 0.001 & 0.342 \\
\hline Eighth year of spell & 0.254 & 0.237 & 0.283 & 1.290 & -1.254 & 0.247 & 0.000 & 0.285 \\
\hline Ninth year of spell & 0.568 & 0.241 & 0.018 & 1.766 & & & & \\
\hline Age $35-44$ & -1.070 & 0.096 & 0.000 & 0.343 & -1.514 & 0.123 & 0.000 & 0.220 \\
\hline Age $45-54$ & -2.177 & 0.105 & 0.000 & 0.113 & -2.703 & 0.149 & 0.000 & 0.067 \\
\hline Age 55-64 & -3.409 & 0.119 & 0.000 & 0.033 & -3.912 & 0.171 & 0.000 & 0.020 \\
\hline Age 65+ & -3.883 & 0.125 & 0.000 & 0.021 & -3.877 & 0.156 & 0.000 & 0.021 \\
\hline De facto & -0.203 & 0.126 & 0.107 & 0.816 & -0.268 & 0.158 & 0.090 & 0.765 \\
\hline Separated or divorced & 1.290 & 0.090 & 0.000 & 3.631 & 1.027 & 0.129 & 0.000 & 2.791 \\
\hline Widow & 0.471 & 0.149 & 0.002 & 1.602 & 0.229 & 0.176 & 0.194 & 1.257 \\
\hline Single never married & -0.196 & 0.130 & 0.131 & 0.822 & -0.133 & 0.174 & 0.446 & 0.875 \\
\hline Number of children & -0.539 & 0.041 & 0.000 & 0.584 & -0.543 & 0.055 & 0.000 & 0.581 \\
\hline $\begin{array}{l}\text { Self-assessed health } \\
\text { rank, } 1 \text { = Excellent }\end{array}$ & -0.228 & 0.116 & 0.050 & 0.796 & -0.558 & 0.126 & 0.000 & 0.573 \\
\hline $\begin{array}{l}\text { Highest qualification } \\
\text { tertiary }\end{array}$ & -0.106 & 0.086 & 0.216 & 0.899 & -0.304 & 0.143 & 0.034 & 0.738 \\
\hline $\begin{array}{l}\text { Employed } \\
\text { Real equivalised gross }\end{array}$ & -0.960 & 0.083 & 0.000 & 0.383 & -0.831 & 0.110 & 0.000 & 0.436 \\
\hline $\begin{array}{l}\text { household income ( } \${ }^{\prime} 000 \\
\text { for Aus \& } £^{\prime} 000 \text { for UK) }\end{array}$ & -0.011 & 0.001 & 0.000 & 0.989 & -0.049 & 0.005 & 0.000 & 0.952 \\
\hline $\begin{array}{l}\text { Loan-to-value ratio (\%) } \\
\text { No. of times extracted }\end{array}$ & 0.007 & 0.002 & 0.000 & 1.007 & 0.005 & 0.002 & 0.052 & 1.005 \\
\hline $\begin{array}{l}\text { equity via in situ MEW } \\
\text { during ownership spell } \\
\text { No. of times extracted }\end{array}$ & -0.454 & 0.031 & 0.000 & 0.635 & -0.732 & 0.056 & 0.000 & 0.481 \\
\hline $\begin{array}{l}\text { equity via trading on during } \\
\text { ownership spell }\end{array}$ & -0.608 & 0.104 & 0.000 & 0.545 & -0.420 & 0.171 & 0.014 & 0.657 \\
\hline 2007 & 0.037 & 0.166 & 0.824 & 1.038 & 0.773 & 0.242 & 0.001 & 2.166 \\
\hline
\end{tabular}




\begin{tabular}{|c|c|c|c|c|c|c|c|c|}
\hline \multirow[t]{2}{*}{ Explanatory variables $^{a}$} & \multicolumn{4}{|c|}{ Australia } & \multicolumn{4}{|c|}{ UK } \\
\hline & Coef. & $\begin{array}{l}\text { Std. } \\
\text { error }\end{array}$ & Sig. & $\begin{array}{c}\text { Odds } \\
\text { ratio }\end{array}$ & Coef. & $\begin{array}{l}\text { Std. } \\
\text { error }\end{array}$ & Sig. & $\begin{array}{l}\text { Odds } \\
\text { ratio }\end{array}$ \\
\hline 2008 & -0.333 & 0.190 & 0.080 & 0.717 & 0.610 & 0.269 & 0.024 & 1.840 \\
\hline 2009 & 0.086 & 0.171 & 0.614 & 1.090 & 2.376 & 0.198 & 0.000 & 10.757 \\
\hline 2010 & -0.017 & 0.176 & 0.921 & 0.983 & & & & \\
\hline Sample & \multicolumn{4}{|c|}{33989} & \multicolumn{4}{|c|}{46746} \\
\hline Chi-square & \multicolumn{4}{|c|}{39501.602} & \multicolumn{4}{|c|}{59838.914} \\
\hline Cox and Snell R-square & \multicolumn{4}{|c|}{0.687199} & \multicolumn{4}{|c|}{0.722} \\
\hline Nagelkerke R-square & \multicolumn{4}{|c|}{0.916265} & \multicolumn{4}{|c|}{0.963} \\
\hline
\end{tabular}

Source: Authors' own calculations from the 2001-10 HILDA Survey, 2001-08 BHPS and Understanding Society wave 2.

Note: a. The omitted categories are: Age under 35, legally married and 2001-06 (pre-GFC years). 
Table 6: Predicted probabilities of exit, 2001-2009

(a) Under Australian settings

\begin{tabular}{|l|l|c|c|c|}
\hline Year of & \multirow{2}{*}{$\begin{array}{l}\text { Time } \\
\text { spell }(t)\end{array}$} & interval $^{\text {a }}$ & \multicolumn{3}{|c|}{$\begin{array}{c}\text { Pustralian } \\
\text { institutional settings }\end{array}$} & $\begin{array}{c}\text { UK institutional } \\
\text { settings }\end{array}$ & $\begin{array}{r}\text { UK predicted probabilities - } \\
\text { Australian predicted probabilities }\end{array}$ \\
\hline 0 & & 0.049 & 0.009 & -0.040 \\
1 & {$[0,1)$} & 0.032 & 0.008 & -0.023 \\
2 & {$[1,2)$} & 0.035 & 0.009 & -0.026 \\
3 & {$[2,3)$} & 0.036 & 0.008 & -0.028 \\
4 & {$[3,4)$} & 0.034 & 0.006 & -0.028 \\
5 & {$[4,5)$} & 0.027 & 0.006 & -0.021 \\
6 & {$[5,6)$} & 0.032 & 0.003 & -0.028 \\
7 & {$[6,7)$} & 0.031 & 0.003 & -0.029 \\
8 & {$[7,8)$} & & & \\
\hline
\end{tabular}

(b) Under UK settings

\begin{tabular}{|l|l|c|c|c|}
\hline Year of & \multirow{2}{*}{$\begin{array}{l}\text { Time } \\
\text { spell }(t)\end{array}$} & interval $^{\mathrm{a}}$ & \multicolumn{3}{|c|}{ Adjusted hazard rates at mean UK characteristics } \\
\cline { 3 - 5 } & & $\begin{array}{c}\text { UK institutional } \\
\text { settings }\end{array}$ & $\begin{array}{c}\text { Australian } \\
\text { institutional } \\
\text { settings }\end{array}$ & $\begin{array}{c}\text { Australian adjusted rates - UK } \\
\text { adjusted rates }\end{array}$ \\
\hline 0 & {$[0,1)$} & 0.009 & 0.042 & 0.033 \\
1 & {$[1,2)$} & 0.008 & 0.027 & 0.019 \\
2 & {$[2,3)$} & 0.009 & 0.030 & 0.021 \\
3 & {$[3,4)$} & 0.008 & 0.031 & 0.023 \\
4 & {$[4,5)$} & 0.006 & 0.029 & 0.023 \\
5 & {$[5,6)$} & 0.005 & 0.023 & 0.018 \\
6 & {$[6,7)$} & 0.003 & 0.027 & 0.024 \\
7 & {$[7,8)$} & 0.003 & 0.027 & 0.024 \\
8 & {$[8,9)$} & & & \\
\hline
\end{tabular}

Source: Authors' own calculations from the 2001-10 HILDA Survey, 2001-08 BHPS and Understanding Society wave 2

Note: a. The time interval $[x, y)$ refers to a time period beginning in $x$ and ending just before $y$. 
Figure 1: Hazard rate, Australia and UK, spells in home ownership that were ongoing in 2001 or began in the calendar years 2002 to 2010

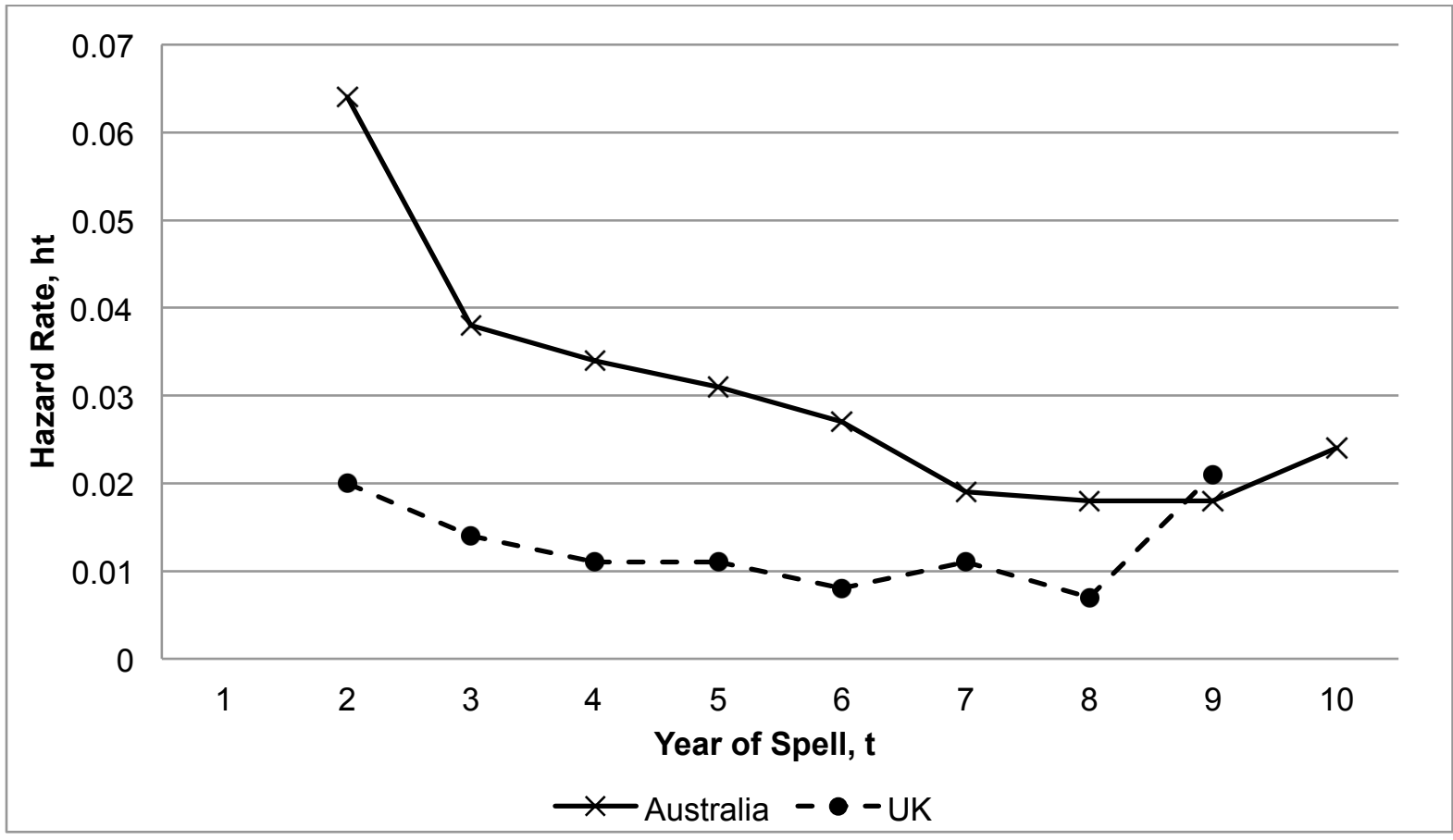

Source: Authors' own calculations from the 2001-10 HILDA Survey, 2001-08 BHPS and Understanding Society wave 2 
Figure 2: Hazard rate, Australia and UK, spells in home ownership that began in the calendar years 2002 to 2010

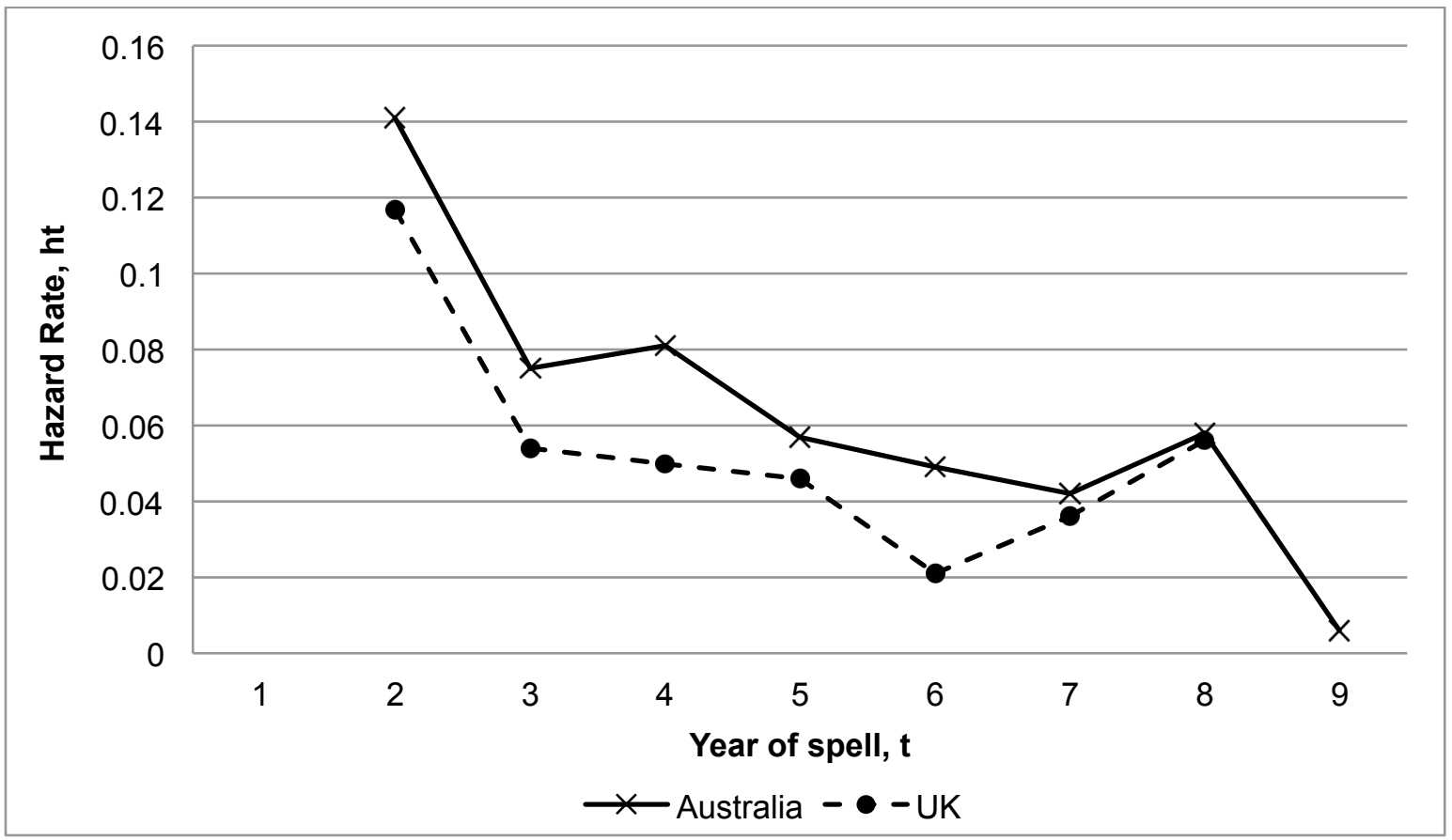

Source: Authors' own calculations from the 2001-10 HILDA Survey, 2001-08 BHPS and Understanding Society wave 2 